\title{
PERANAN PETA SEBAGAI ALAT PENGHUBUNG IDENTITAS KERUANGAN DALAM MITIGASI BENCANA ALAM LONGSOR LAHAN
}

\author{
Oleh: \\ Muhammad Nursa'ban \\ Jurdik. Geografi, FISE UNY \\ mnsaban@yahoo.com
}

\begin{abstract}
$\underline{\text { Abstrak }}$
Longsor lahan merupakan salah satu bencana alam geologi yang dapat menimbulkan korban jiwa dan kerugian material yang sangat besar, seperti terjadinya pendangkalan, terganggunya jalur lalu lintas, rusaknya lahan pertanian, permukiman, jembatan, saluran irigasi dan prasarana fisik lainnya. Proses terjadinya longsor lahan bersifat mengubah atau merusak terhadap konfigurasi permukaan bumi. Dalam upaya mengurangi dan mencegah resiko bencana diperlukan informasi keruangan yang dapat mengidentifikasi potensi kerentanan longsor lahan di suatu wilayah.

Salah satu cara untuk membuat informasi dalam mengidentifikasi potensi kerentanan longsor lahan yaitu menggunakan peta. Peta dapat menggambarkan secara grafis atau visual dimensi ruang dan waktu yang terkonsep terhadap suatu atau beberapa fenomena seperti halnya potensi kerentanan longsor lahan. Peta dapat menggambarkan hubungan yang jelas secara matematis antar faktor-faktor yang berpengaruh dalam kejadian longsor lahan. Disamping itu peta dapat mengidentifikasi tingkat kerentanan dan sebaran longsor lahan di suatu wilayah. Dalam pembuatan peta tersebut sejumlah teknik seperti remote sensing dan Sistem Informasi Geografi dapat digunakan ditunjang teknik analisis dari ilmu tanah dan hidrologi.

Hasil pemetaan terhadap potensi longsor lahan dapat diwujudkan dalam bentuk peta tingkat kerentanan dan sebaran potensi longsor lahan di suatu wilayah sebagai hasil dari proses tumpang susun peta-peta tematik yang mendukung kejadian longsor lahan. Pada akhirnya keberadaan peta tersebut akan menjadi upaya dalam mitigasi bencana alam.
\end{abstract}

Kata Kunci: Peta, Longsor, mitigasi 


\section{Pendahuluan}

Indonesia sering dikejutkan dengan adanya bencana longsor lahan di beberapa daerah. Bencana ini tidak hanya menimbulkan korban jiwa, lebih dari itu infrastruktur di daerah tersebut juga terganggu fungsinya. Bencana longsor lahan tersebut terjadi tidak lepas dari keadaan alam dan perilaku manusia. Posisi Indonesia yang terletak pada pertemuan tiga lempeng yaitu lempeng benua Australia, lempeng Benua Eurasia, dan lempeng Samudera Pasifik, sehingga terbentuklah jalur gunung api aktif dan jalur gempa bumi. Adanya tumbukan lempeng-lempeng tersebut maka terjadi zona penunjaman yang merupakan jalur gempa bumi dan membentuk undulasi di busur kepulauan dengan kemiringan terjal sampai sangat terjal. Disamping itu, Indonesia juga terletak di daerah tropis dengan curah hujan yang tinggi, dan memiliki topografi yang bervariasi. Secara geologis, geomorfologis, dan klimatologis Indonesia selalu dihadapkan pada bencana alam seperti: letusan gunung api, gempa bumi, longsor lahan, dan banjir. Selain itu faktor manusia juga dalam mengelola lahan turut menjadi pemicu terjadi bencana.

Salah satu bencana alam yang sering terjadi di Indonesia adalah longsor lahan. Frekuensi kejadian atau kemungkinan terjadinya bencana longsor lahan relatif lebih besar dari pada frekuensi kemungkinan terjadinya bencana geologi yang lain. Titik-titik kejadian longsor lahan juga tersebar luas di seluruh wilayah Kepulauan Indonesia daripada sebaran lokasi kejadian bencana geologi lain. David J. James (1978); yang dikutip Dumanski (1997: 244) memberikan definisi longsor lahan"....is the process by which earth materials (bedrocks, unconsolidated sediments and soils) are transported down slopes by gravity". Thornbury (1969: 76) mendefinisikan longsor lahan sebagai gerakan massa dari rombakan batuan yang tipe gerakannya meluncur atau menggeser (sliding/slipping), berputar (rotational) yang disebabkan oleh gaya gravitasi sehingga gerakannya lebih cepat dan kandungan airnya lebih sedikit.

Longsor lahan menurut Direktorat Geologi dan Tata Lingkungan (1981) yaitu suatu produk gangguan keseimbangan lereng yang menyebabkan bergeraknya massa tanah dan batuan ke tempat yang lebih rendah. Gerakan ini dapat terjadi pada tanah yang hambatan tanah/batuannya lebih kecil dibanding dengan berat massa tanah/batuan itu sendiri. Hal ini secara sederhana dapat dilihat pada Gambar 1.

Sitanala Arsyad (1989: 23) menyatakan longsor lahan akan terjadi apabila terdapat tiga keadaan, yaitu: (1) Terdapat lereng yang cukup curam sehingga massa tanah dapat bergerak atau meluncur secara cepat ke bawah. (2) Adanya lapisan di bawah permukaan massa tanah, yang kedap air dan lunak, yang akan menjadi bidang luncur. (3) Adanya cukup kandungan air dalam tanah sehingga massa tanah yang tepat di atas lapisan kedap tersebut menjadi jenuh. 
Berdasarkan data yang dihimpun Direktorat Vulkanologi dan Mitigasi Bencana Geologi, Direktorat Jendral Geologi dan Sumber Daya Mineral (2003), setiap tahun beberapa wilayah di Indonesia mengalami longsor lahan. Longsor lahan tersebut mengakibatkan kerugian materi dan juga korban jiwa. Kejadian longsor lahan umumnya berskala kecil, tidak sehebat gempa bumi, tsunami maupun gunung meletus sehingga perhatian pada masalah ini umumnya tidak terlalu besar, tambah lagi bahaya bencana longsor lahan kurang diperhatikan dalam perencanaan pembangunan. Keadaan alam yang bergunung-gunung di setiap wilayahnya, Indonesia berpotensi mengalami longsor lahan. Salah satu upaya untuk mengurangi dan mencegah terjadinya longsor lahan yaitu dengan mengetahui persebaran daerah yang rawan terhadap longsor lahan. Setiap lahan memiliki tingkat kerentanan longsor lahan yang beragam. Hal tersebut dipengaruhi oleh beberapa faktor penyebab. Cook dan Dornkampm (1994: 148) menyatakan faktor penyebab longsor lahan meliputi faktor pasif dan faktor aktif. Faktor pasif mengontrol terjadinya longsor lahan sedangkan faktor aktif pemicu terjadinya longsor lahan (Thornbury, 1969). Faktor pasif meliputi faktor topografi, keadaan geologis/litologi, keadaan hidrologis, tanah, keterdapatan longsor sebelumnya dan keadaan vegetasi. Faktor aktif yang mempengaruhi longsor lahan diantaranya aktivitas manusia dalam penggunaan lahan dan faktor iklim.

Kerentanan longsor lahan menggambarkan keadaan kecenderungan lereng alami atau potensi suatu medan untuk terjadinya gerakan massa atau ketidakseimbangan yang dibentuk oleh lingkungan fisik maupun non fisik. Penilaian tingkat bahaya kerentanan longsor lahan menggunakan pendekatan Satuan Unit Lahan sebagai satuan analisis dan menunjukan kelas suatu bentuk lahan sejenis dalam hubungannya dengan karakteristik satuan unit lahan tersebut. Penentuan tingkat kerentanan ini dilakukan dengan cara kualitatif dan kuantitatif. Cara kualitatif yaitu dengan cara menafsirkan keadaan bentuk permukaan bumi (morfologi), keadaan batuan (geologis), keadaan tanah, keadaan perairan (hidrologis) dan penggunaan lahan. Cara kuantitatif yaitu dengan pemberian skor atau pengharkatan karakteristik unit lahan yang telah ditentukan melalui tumpang susun peta.

Cara kedua melalui pemanfaatan peta dirasa lebih efektif dengan memanfaatkan data-data sebelumnya yang diolah melalui proses kartografi menggunakan teknik penginderaan jauh dan Sistem Informasi Geografi (SIG). Peta sebagai instrumen yang dapat menggambarkan suatu fenomena secara grafis dengan menggunakan perbandingan (skala) sehingga harapannya lebih komunikatif dan informatif dalam menyampaikan informasi kebumian seperti halnya longsor lahan. Saat ini, peta berperan strategis dalam menyajikan informasi keruangan karena lebih mudah diterima oleh khalayak secara cepat 
tanpa harus memaknai konsep-konsep fenomena kebumian yang ditampilkannya.

Peta mampu memberikan hubungan yang jelas secara matematikal antara obyek-obyek yang digambarkan dan penyajiannya faktor-faktor yang berpengaruh terhadap kejadian longsor lahan. Peta juga dapat menunjukkan tingkat besaran potensi longsor lahan melalui proses tumpang susun berbagai peta-peta tematik yang berkaitan dengan pendukung longsor lahan. Lebih khusus lagi secara tematis peta mampu menyajikan data sesuai dengan tema yang diperlukan dalam analisis longsor lahan.

\section{Peta Sebagai Alat Penghubung Identitas Keruangan}

Keruangan hemat saya dapat diperluas maknanya pada hubungan manusia dengan alam dengan dimensi masing-masing. Dimensi-dimensi tersebut meliputi jarak, luas, dan arah, serta hubungan diantara ketiganya. Gambaran ketiga dimensi tersebut dapat divisualkan melalui media peta dengan proses yang berlangsung dalam menggambarkannya. Fungsi peta dalam hal ini menghubungkan identitas atau fenomena yang ada di alam menjadi informasi yang bermakna bagi manusia. Oleh karena itu dengan membaca identitas alam tersebut, manusia dapat merencanakan, membuat, dan menindaklanjuti kehidupannya pada saat berinteraksi dan interelasi dengan alam sekitar. Identitas alam digambarkan dalam bentuk peta-peta tematik yang menyajikan informasi tema tertentu sesuai dengan kebutuhan si pembut peta, seperti peta kemiringan lereng, peta curah hujan, peta kedalaman efektif tanah, peta penggunaan lahan, dan lain sebagainya. Peta berperan sebagai penyaji informasi spasial yang paling representatif dalam masalah ini. Informasi tematis berupa kondisi fisik suatu wilayah seperti jenis tanah, kemiringan lereng, ketinggian, erodibilitas, curah hujan, penggunaan lahan, kondisi geologis, dan kedalaman tanah efektif dapat dijadikan sebagai suatu informasi yang dapat dikonversikan ke dalam bentuk peta. Selain itu kondisi sosial dan perkembangan teknologi juga dapat menjadi rujukan terhadap informasi spasial wilayah yang bersangkutan.

Kumpulan beberapa peta yang terkait dengan suatu analisis diolah melalui proses SIG ini, merupakan pendekatan paling rasional yang dapat menjadi alat penentu tingkat potensi longsor di suatu wilayah. SIG merupakan suatu metoda analisis data yang dilakukan dengan prinsip - prinsip geografis dengan jalan penampakan data yang diperoleh. Metode analisis inilah yang digunakan untuk pengambilan kesimpulan dalam melakukan optimasi, peramalan daerah potensial, pembuatan peta tematik, dan sekaligus analisis dampak lingkungan.

Pola hubungan antara data, Sistem Informasi Geografis (SIG), dan proses pengambilan kesimpulan maupun keputusan menurut A Pinem (1995;5) 
disajikan dalam bentuk diagram pada gambar 2. Peran data spasial jelaslah memberikan kemudahan bagi pembuat kebijakan maupun perencana pembangunan dan peneliti untuk dijadikan sebagai rujukan dalam pengambilan kesimpulan. Kondisi lahan yang mengalami longsor yang terjadi akhir - akhir ini merupakan kasus yang perlu penanganan segera sebelum kerugian yang semakin besar terjadi. Tidaklah menjadi tanggung jawab warga sekitar saja tetapi akademisi juga berperan penting dalam mengukur besaran tingkat longsor lahan yang potensial di suatu wilayah. Informasi spasial melalui peta memberikan data/informasi yang komplek dan lebih akurat. Perkembangan teknologi informasi semakin memudahkan para ahli lingkungan memberikan sumbangan keputusan-keputusannya yang lebih dapat dipertanggung jawabkan.

Integrasi teknologi penginderaan jauh yang menghasilkan peta lokasi suatu wilayah dipadukan dengan Sistem Informasi Geografis merupakan salah satu alternatif informasi spasial yang baru. Pengolahan pemetaan dengan basis komputer yang marak belakangan ini lebih memudahkan dalam mengumpulkan data-data spasial. Kemajuan teknologi ini mengantarkan kita lebih mudah dalam menganalisis kondisi tata ruang di suatu wilayah dan menunjang proses perencanaan terutama pengumpulan dan penyediaan data spasial. SIG dengan basis komputer (digital) ini mampu menyediakan data secara temporal sampai dengan data mutakhir dengan cepat. Ketepatan dan kecepatan data yang dihasilkan diharapkan dapat menggantikan posisi peta peta manual yang tingkat akurasinya sudah mulai memudar. Selama ini memang teknologi ini belum berkembang meluas di masyarakat. Meskipun demikian terobosan - terobosan untuk memberikan data/informasi spasial kepada masyarakat secara langsung tanpa harus menempuh pendidikan khusus sudah mulai berkembang. Ada beberapa situs di internet yang dapat diakses bebas oleh masyarakat yang memberikan informasi langsung kondisi riil informasi spasial suatu wilayah. Perubahan - perubahan yang terjadi dan kondisi kualitas lahan di suatu wilayah dapat diikuti perkembangannya tanpa harus turun ke lapangan.

Rujukan informasi spasial ini dapat dimanfaatkan sebagai penghubung identitas alam dengan manusia yang menerjemahkannya. Dipertegas Sukendra Martha $(1995 ; 4)$ Pentingnya informasi spasial melalui peta sebagai rujukan dalam keberhasilan pembangunan otonomi daerah sangat dirasakan mengingat kebutuhan data, ketiadaan dan keterbatasan dalam bentuk data keruangan memang masih menjadi permasalahan nasional yang masih dihadapi. 


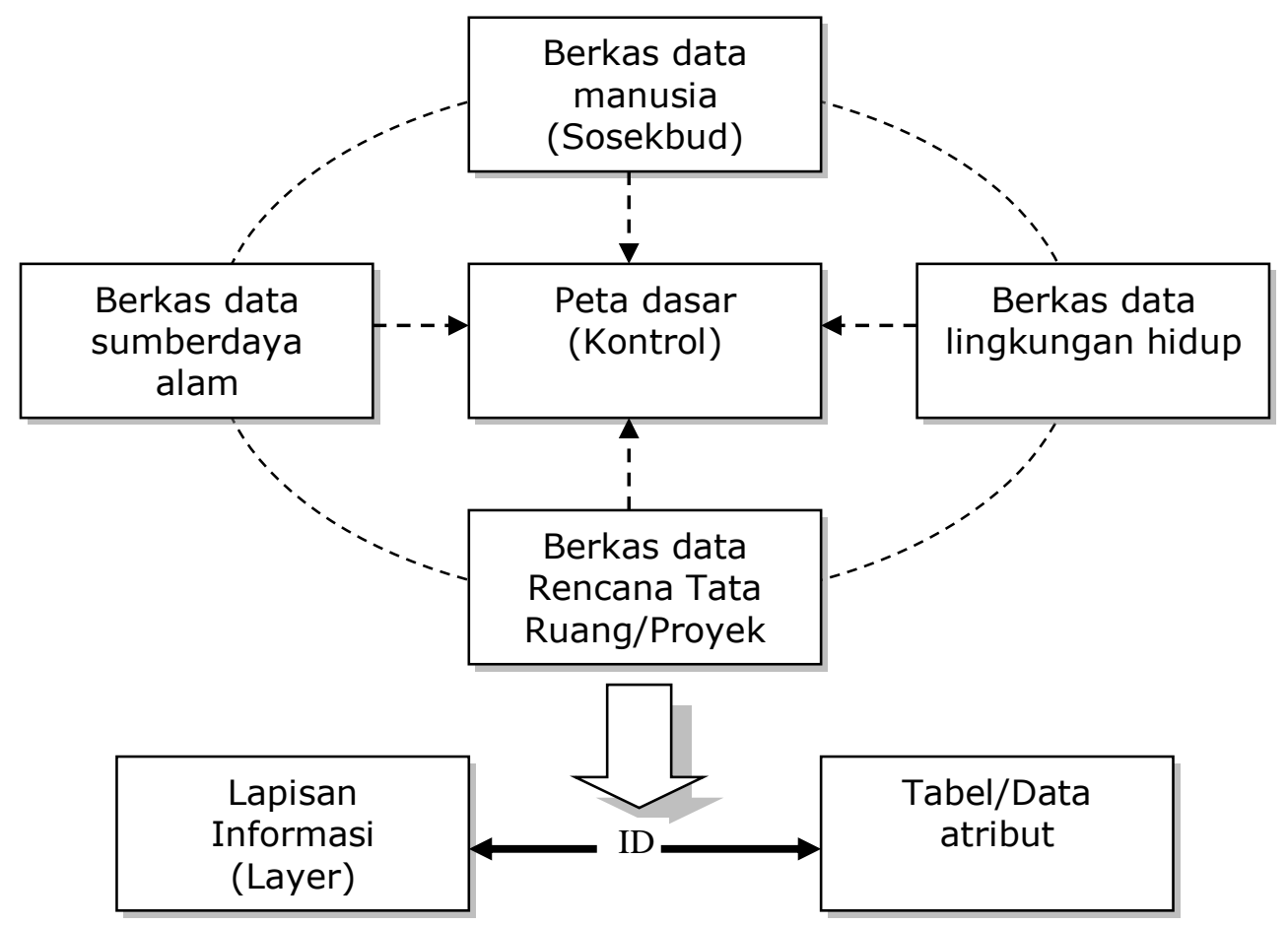

Gambar 2.

Model basis data SIG Tata Ruang (sumber; A. Pinem (1995))

\section{Mitigasi Bencana Alam (Hazard Mitigation) Longsor Lahan}

Menurut Sudibyakto (1985: 3) mitigasi bencana alam merupakan tindakan untuk mengurangi dampak bencana dan hampir sama dengan kegiatan pencegahan. Ditambahkan oleh Sutikno (1994: 23) mitigasi adalah suatu tindakan sebelum bencana terjadi untuk mengurangi seminimal mungkin kerugian harta benda atau korban jiwa. Pada prinsipnya upaya mitigasi dapat dilakukan melalui pendekatan non-struktural seperti peraturan perundangan, penyuluhan, insentif, dan pengembangan sistem peringatan demi bahaya. Tindakan mitigasi terdiri atas mitigasi pasif dan aktif. Mitigasi pasif berupa pengembangan tindakan-tindakan seperti peraturan tentang bangunan, tata guna lahan, tata ruang kota, pemasangan rambu dan tanda bahaya. Mitigasi aktif mencakup tindakan-tindakan yang memerlukan kontak langsung dengan penduduk yaitu melalui penyuluhan sosial, pemugaran rumah, relokasi penduduk dari daerah rawan bencana ke daerah yang aman. Mitigasi aktif 
tidak akan berfungsi tanpa mitigasi pasif (Soetarso, 1997; dalam Sudibyakto 1985: 3).

Pusat Studi Bencana Alam (PSBA) UGM (2001) menyatakan upaya mitigasi bencana alam longsor lahan dapat dilakukan dengan tiga cara yaitu 1) mitigasi bencana alam longsor lahan secara fisik berupa tindakan pemotongan tebing dan penggalian batuan, pembuatan talud, pembuatan kawat pengikat batuan yang lapuk, pembuatan teras sesuai kontur, teras bangku, penanaman pohonpohon, dan pembuatan saluran. 2) secara sosial upaya pencegahan dan penanggulangan bencana longsor lahan dengan menekan sedikit mungkin atau tanpa ada korban jiwa dan kerugian harta benda melalui kegiatan penyelamatan yaitu, pemindahan penduduk secara permanen dan pemindahan penduduk sementara (evakuasi saat terjadi bencana). 3) mitigasi bencana alam longsor lahan secara vegetatif yaitu dengan memperhatikan keadaan vegetasi meliputi, pemilihan jenis vegetasi yang sesuai dan pengaturan jarak tanaman.

\section{Peranan Peta dalam Upaya Mitigasi Bencana Alam Longsor Lahan.}

Sumbangan peta dalam upaya mitigasi bencana alam longsor lahan dapat dilakukan melalui proses kajian terhadap potensi longsor lahan dimulai dari penentuan sampel lahan, proses pengharkatan nilai kerentanan longsor lahan menggunakan teknik SIG sampai penyajian data satuan unit lahan dengan nilai besaran longsor lahan dan persebarannya. Peran peta ini sebagai alat analisis memahami, apa, di mana, dan berapa tingkat kerentanan longsor lahan terjadi di suatu wilayah.

Penentuan sampel lahan untuk mengkaji longsor lahan dilakukan melalui penentuan satuan unit lahan untuk sampel. Satuan unit lahan ini diperoleh melalui teknik purposive area sampling dengan cara tumpang susun peta; misalnya kondisi geologi, jenis tanah, kemiringan lereng dan tata guna lahan. Hasil tumpang susun akan dihasilkan klasifikasi satuan unit lahan. Dari tiap satuan unit lahan tersebut kemudian diambil satu titik untuk dijadikan sampel, di mana setiap titik mewakili satu satuan unit lahan yang memiliki ciri dan karakteristik yang sama.

Setelah peta menyajikan satuan unit lahan untuk sampel, langkah berikutnya yang dilakukan peta adalah memproses penilaian kerentanan. Pengharkatan nilai kerentanan longsor lahan melalui cara Penskoran atau pengharkatan sesuai dengan kriteria penilaian yang telah ditentukan melalui peta-peta tematik yang mendukung terjadinya longsor lahan. Menafsirkan variabel pendukung terjadinya longsor lahan pada tiap satuan unit lahan untuk mengetahui karakteristik lahan yang berpengaruh terhadap longsor lahan di daerah penelitian meliputi: (a) faktor aktif yaitu data curah hujan dan aktivitas 
manusia berupa penggunaan lahan. (b) faktor pasif di antaranya kemiringan lereng, tekstur tanah, permeabilitas, kedalaman efektif tanah, solum tanah, tingkat pelapukan batuan, dan kerapatan vegetasi.

Pada bagian akhir setelah dilakukan pengukuran tingkat kerentanan longsor lahan sesuai data peta tematik, hasil uji laboratorium dan, data dokumen yang ada, kemudian dibuat peta tingkat kerentanan potensi longsor pada setiap satuan unit lahan. Contoh peta satuan unit lahan dapat dilihat pada gambar 3.

Peta yang digunakan dalam menentukan tingkat kerentanan longsor lahan tidaklah semuanya menggambarkan informasi sebenarnya. Peta hanya menyajikan sebagian informasi yang penting dan menyesuaikan dengan media tampilannya. Informasi yang dipilih dan dianggap penting ditampilkan melalui simbol-simbol berdasarkan beberapa kriteria penggolongannya. Peta dibuat menurut asumsi tertentu sehingga syarat dengan kepentingan tertentu terutama pembuat peta itu sendiri. Di dalamnya peta mengandung unsur generalisasi, penskalaan, dan manipulasi simbol atas realitas yang nampak dan dikonsepsikan.

Kompilasi peta dengan data yang akurat dapat menyajikan suatu hasil penrhitungan atau kajian yang setidaknya mendekati kebenaran. Oleh karena itu peta memberikan peluang yang besar dapat diterima oleh khalayak melalui kelebihan visual dan grafisnya. Data diolah dan dianalisis secara benar kemudian divisualkan oleh peta akan menghasilkan luaran yang cepat dan tepat.

\section{Penutup}

Peta dengan keunggulan grafisnya dapat menyajikan informasi potensi kerentanan longsor lahan secara cepat dan tepat karena dapat menggambarkan dimensi ruang dan waktu yang terkonsep suatu fenomena. Kualitas, kuantitas, kecenderungan dan sebaran fenomena kebumian termasuk longsor lahan dapat diketahui pada posisi dan konteksnya, sehingga dimungkinkan dianalisis lebih lanjut sesuai dengan tujuan.

Peran strategis peta sebagai alat pengukur potensi kerentanan longsor lahan dapat ditunjukkan melalui proses analisisnya yang menghasilkan tingkat kerentanan dan sebaran dari longsor lahan di suatu wilayah 


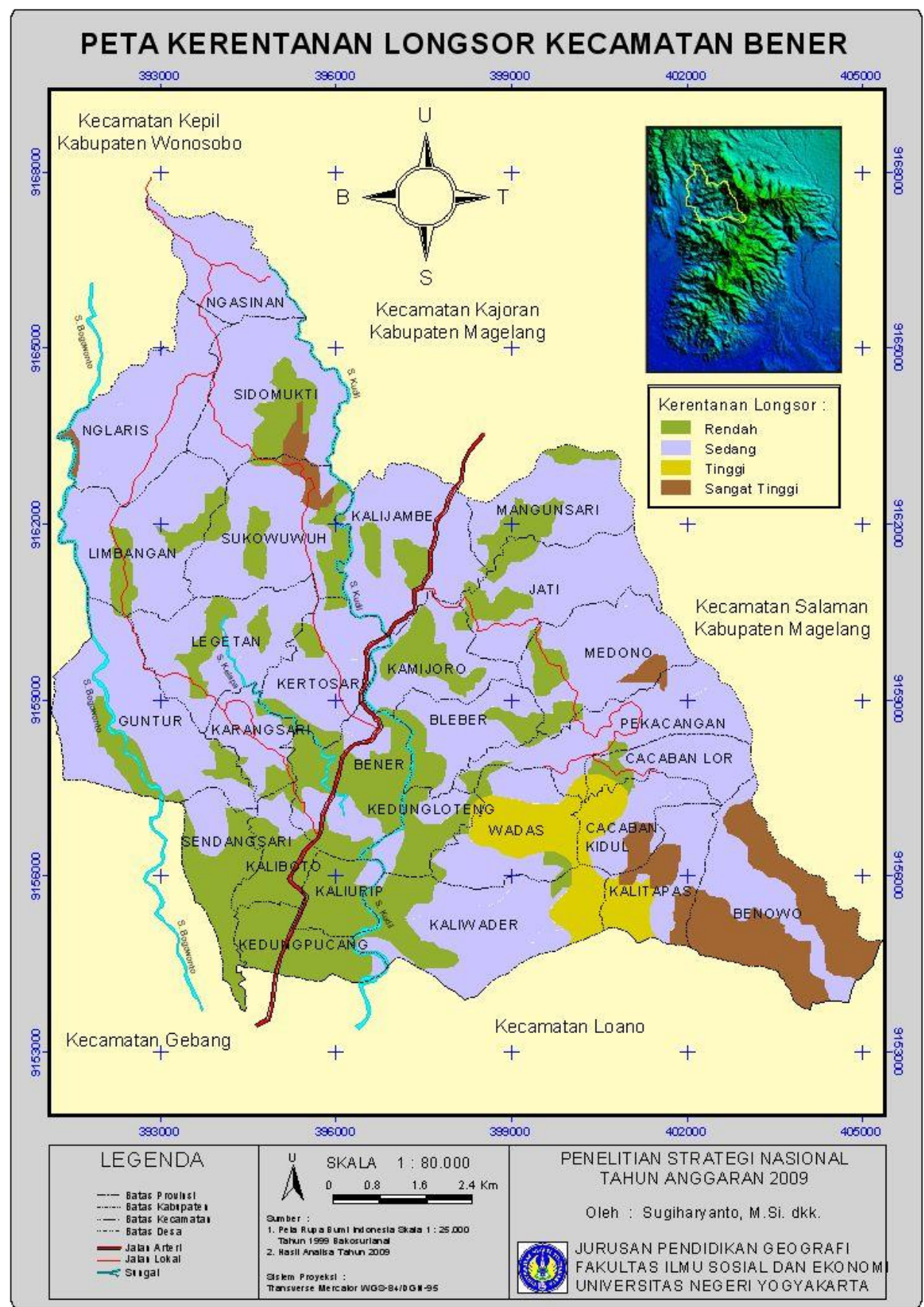

Gambar 3. Contoh peta Kerentanan Longsor Lahan di Kecamatan Bener Kab. Purworejo. (sumber: peta hasil penelitian stranas 2009, a.n. Sugiharyanto, dkk) 


\section{Daftar Pustaka}

Ajang Pinem 1995. Konsep Kelembagaan Sistem Informasi Geografis Tata Ruang (makalah seminar). Yogyakarta: Fakultas Geografi UGM

Cook, R.U. dan Doornkamp, J.C. (1994). Geomorphology in Enviromental Management - and New Introduction. Amsterdam: Elsevier.

Heri Tjahjono. (2003). “ Kerentanan Medan Terhadap Longsoran dan Stabilitas Lereng di Daerah Kecamatan Gunung Pati Kota Semarang" Suatu Aplikasi Pendekatan Survey Medan)" Tesis. Yogyakarta: Program Pascasarjana Universitas

Pusat Studi Bencana Alam UGM dan Bappeda Kabupaten Kulon Progo. (2001). Penyusunan Sistem Informasi Penanggulangan Bencana Alam Tanah Longsor di Kabupaten Kulon Progo. Yogyakarta:PSBA UGM.

Sitanala Arsyad. (1989). Konservasi Tanah dan Air. Bogor: Penerbit IPB

Sudibyakto. (1985). Mitigasi Bencana Alam Gunung Berapi. Yogyakarta:Andi Offset.

Sukendra Martha, M.Sc. MApp.Sc. 1995. Rujukan Informasi Spasial untuk Menunjang Keberhasilan Pembangunan Daerah (makalah seminar). Yogyakarta: Fakultas Geografi UGM

Sutikno. (1994). "Pendekatan Geomorfologi untuk Mitigasi Bencana Alam Akibat Gerakan Massa Tanah atau Batuan". Prosiding di UGM, 16-17 September. Yogyakarta:Fakultas Geografi UGM. (2002). " Evaluasi Tingkat Bahaya Tanah Longsor Kabupaten Kulonprogo Daerah Istimewa Yogyakarta". Prosiding di UGM, 12-13 Maret, Yogyakarta: PSBA UGM. 